\title{
Characterization of space around Japanese traditional buildings: "Visible Music" on the approach to Horyuji Temple, Saiin (West Compound)
}

\author{
M. Yasuhara ${ }^{1}$, T. Sakiyama ${ }^{1} \&$ K. Iibuchi ${ }^{2}$ \\ ${ }^{1}$ Department of Architecture, Akita Prefectural University, Japan \\ ${ }^{2}$ Department of Architecture, Tohoku University, Japan
}

\begin{abstract}
The psychological sense inherent in the architectural space cannot be presented in architectural drawings, plans, sections, and elevations. What is needed is not the history of architectural style but the history of architectural space. For example, while approaching a building an observer will be influenced by constantly changing scenes and environment. Around Japanese traditional architecture, these changing scenes occur under the influence of an "inner domain of eaves" as proposed in the first author's earlier publication "Japanese Space in Architecture", 1996. This paper shows a sequence of views and characteristics of space observed while approaching Horyuji Temple, Saiin (West compound) which is considered to be the oldest wooden architecture (C7 $\mathrm{AD} \sim \mathrm{C} 8 \mathrm{AD}$ ) existing in the world, and was registered as a UNESCO "World Heritage" site in 1993.

In addition, a new concept of "Visible Music" is proposed to characterize certain unique features of Japanese wooden architecture. It is quite different from the concept of "Frozen Music". As soon as the observer can see the underside of eaves the roof disappear from the observer's sight. Such sequences tend to occur continuously while approaching common Japanese traditional buildings as well. The lines of radiation in this observation process do not always appear and disappear from the nearest building. That is, the order in which they appear does not always follow the order of distance from the nearest building to the farthest building. Particular attention is paid to the role of roofs and eaves in the perception of Japanese traditional architecture. "Visible Music" is piped as one approaches Horyuji Temple, Saiin (West compound).

Keywords: Visible Music, Frozen Music, inner domain of eaves, sequence, Horyuji temple, history of architectural space, world heritage.
\end{abstract}




\section{Introduction}

In our previous paper "Characterization of Space around Japanese Traditional Buildings. Part 1. The Case of Horyuji Temple" [3], and "Characterization of Space around Japanese Traditional Buildings. Part 2. The Physical and Psychological Effects of View of Eaves" [4], we introduced a concept of "inner domain of eaves", a zone that is influenced by the underside of eaves. The boundary of this domain is the line of intersection of the extension from the underside of eaves at the same slope and the eye level of observer. A brief explanation of this domain is given below.
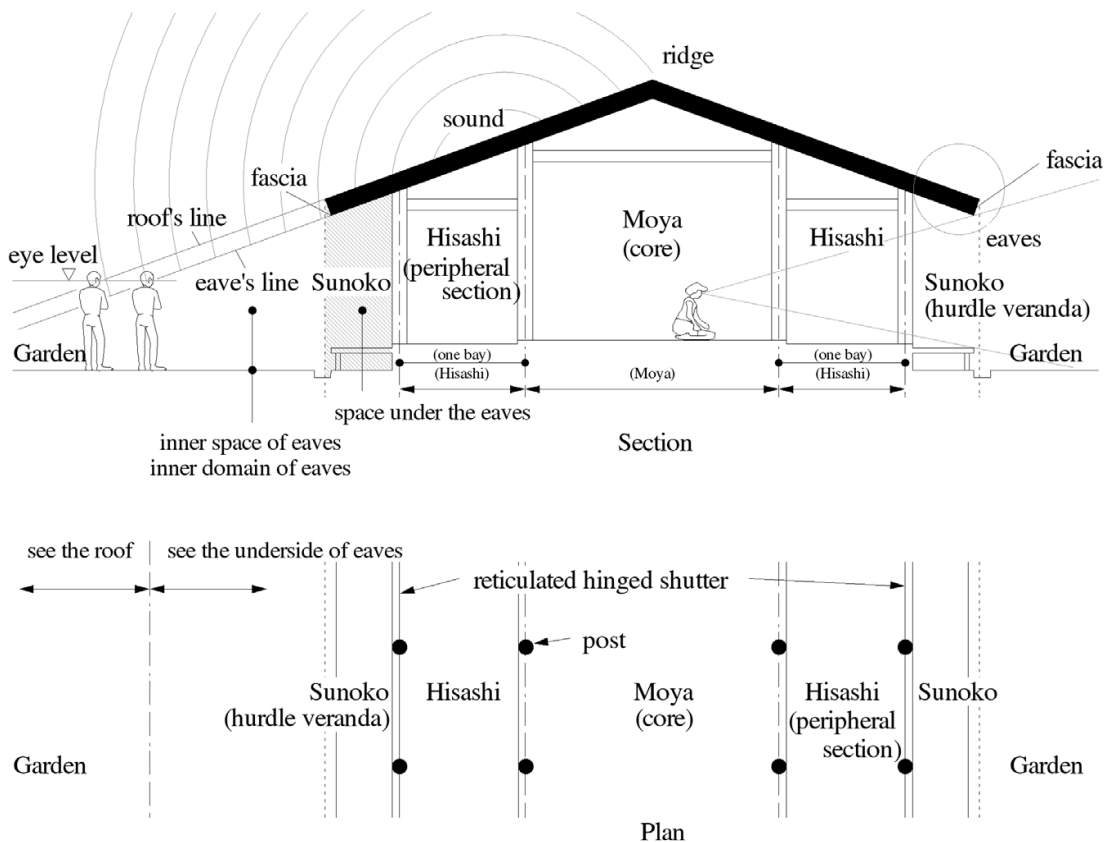

$\begin{array}{ll}\text { Moya: } & \text { core } \\ \text { Hisashi: } & \text { peripheral sections---usually one bay(ken) in depth } \\ \text { Sunoko: } & \text { hurdle veranda }\end{array}$

Figure 1: Inner Domain of Eaves (inner space of eaves). Above: sectional composition of side view, below: sectional composition of plan view.

When approaching from a distance, roofs influence the observer's perception of space at first. Among the buildings with the same inclination of roofs and undersides of eaves, as soon as the observer passes the point where only the fascia can be seen the roof disappears from his sight. And also as soon as he crosses the boundary of "inner domain of eaves" his perception is influenced by the underside of eaves. And the fascia disappears from the observer's sight. This transition takes place in an instant and is, therefore, quite dramatic. The observer 
can anticipate a dramatic change of scene. From this instant the observer becomes involved in the space of eaves which we have called "inner domain of eaves" (see Fig. 1), "inner space of eaves" (see Fig. 1). This includes the space under eaves (nokishita) but is wider.

If a building has several roofs with different heights, such as the Gojyu-no-to (Pagoda) each roof generates its own "inner domain of eaves". As the observer gets closer to the building he gets increasingly strong impressions of the undersides of eaves. This interplay of roofs, fascia and underside of eaves is one of the characteristics of traditional Japanese architecture.

In this paper the line of the extension from the underside of eaves is named as "the eave's line" and also the line of the extension from the surface of the roof is named as "the roof"s line".

\section{The radiation of "the roof's line" and "the eave's line" in Horyuji Temple}

In this paper, from the viewpoint of the vertical section the following shows "inner domains of eaves" of Horyuji Temple, Saiin (West Compound) that are drawing on the section (Fig. 2) and on the plan (Fig. 3).

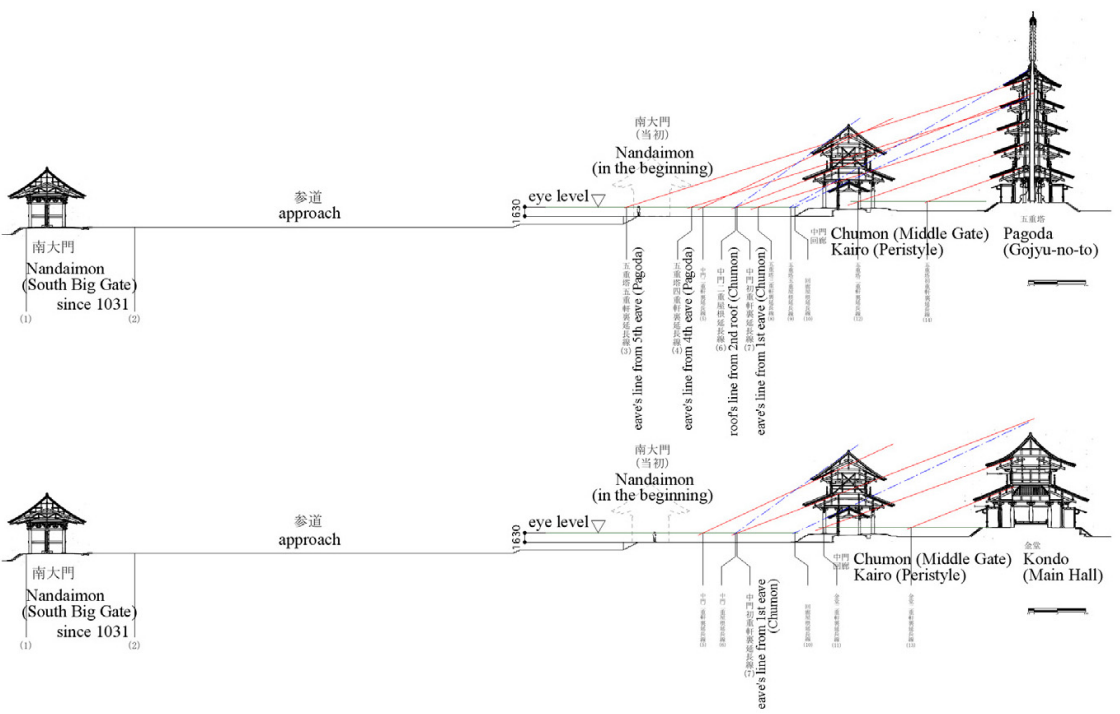

Figure 2: The section of "inner space of eaves" in Horyuji Temple, Saiin.

"The roof's line" and "the eave's line" radiate in turn from every building, which has their own several roofs and eaves.

As soon as the observer can see the underside of the eaves the roof disappear from the observer's sight. Such sequences tend to occur continuously from every building while approaching. 


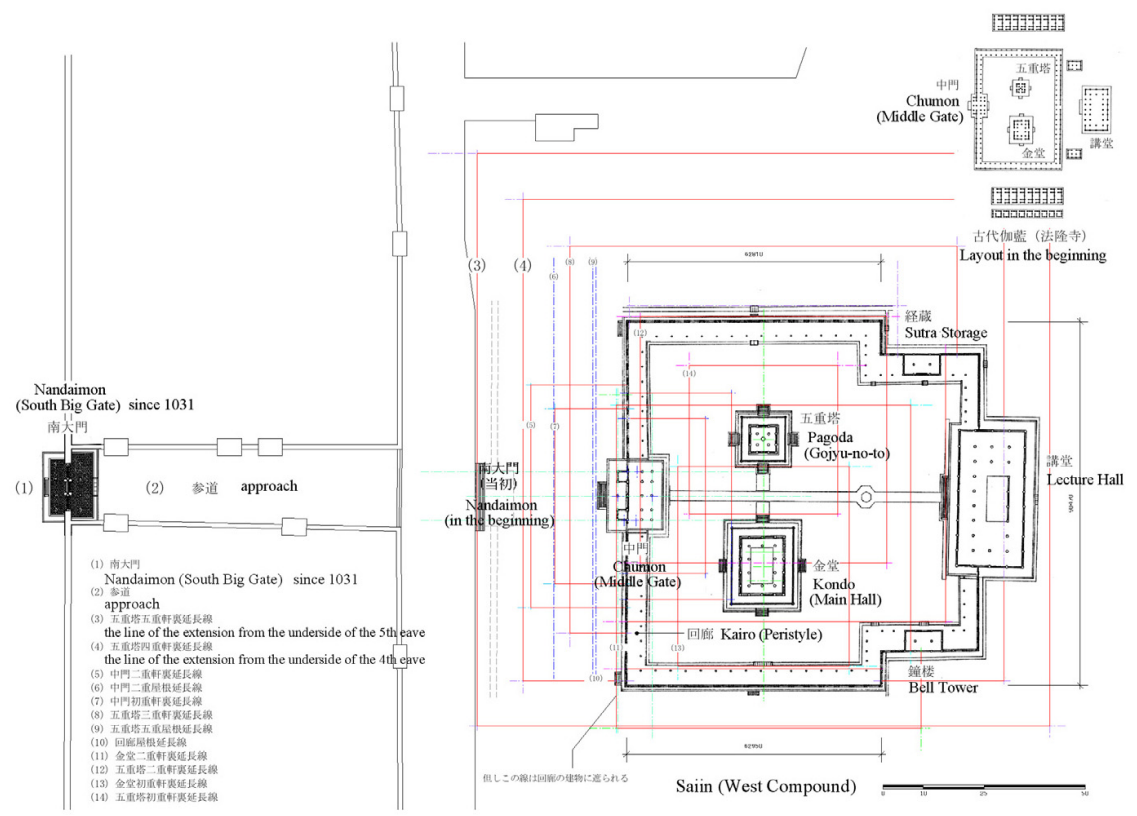

Figure 3: The plan of "inner domain of eaves" in Horyuji Temple, Saiin.

The lines of radiation in this observation process do not always appear and disappear from the nearest building. That is, the order in which they appear does not always follow the order of distance from the nearest building to the farthest building.

Before approaching, at first the observer meets the façade in front, far from the Saiin (West Compound). It looks like the elevation (Fig. 4). The observer can see every building in the Saiin (West Compound).

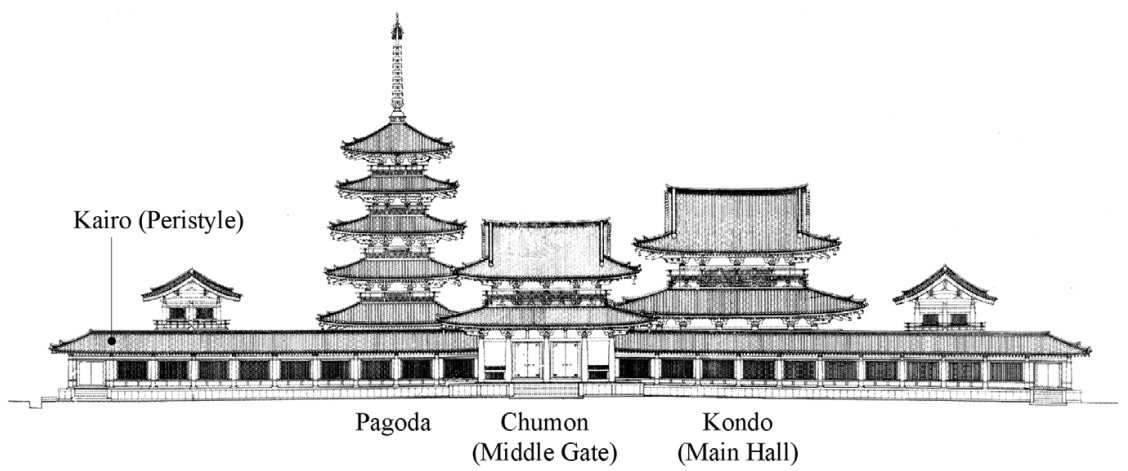

Figure 4: The elevation of Horyuji Temple, Saiin. 
In the Saiin (West Compound), the Gojyu-no-to (Pagoda) and Kondo (Main Hall) stand side by side at a same distance from the observer. The place of Chumon (Middle Gate) is situated between Pagoda and Main Hall and also in front of them. That layout of buildings generates the subtle and complex radiation on the approach (Fig. 2, Fig. 3).

While walking on the approach, feeling the radiation of those lines the observer is like reading the music score.

Although the Gojyu-no-to (Pagoda, Fig. 5) in Horyuji Temple, Saiin (West Compound) looks like 5-storey pagoda, it is one-storey building. In China there is the 5-storey pagoda, Wooden Pagoda (1056, Fig. 6) in Butsuguji Temple, which have five floors with shorter eaves. There are big differences between Japanese traditional buildings and Chinese traditional buildings.

The interior space of Japanese Gojyu-no-to (Pagoda) is only in the first floor. In the space above the first floor there are no floors, no natural lighting and no artificial lighting, therefore it is always pitch-dark. Though the facades have windows, which cannot be opened to the air and the natural light, it is dummy. The interior space is for the structure where are occupied by structural members of framework like columns and beams (Fig. 7). That is why this building was designed for the facades. It means the importance of roofs, eaves and underside of eaves on their external appearance. Furthermore, their influences of radiation from which roofs, eaves and underside of eaves generate to the approach is an important point of view about space around Japanese traditional buildings.

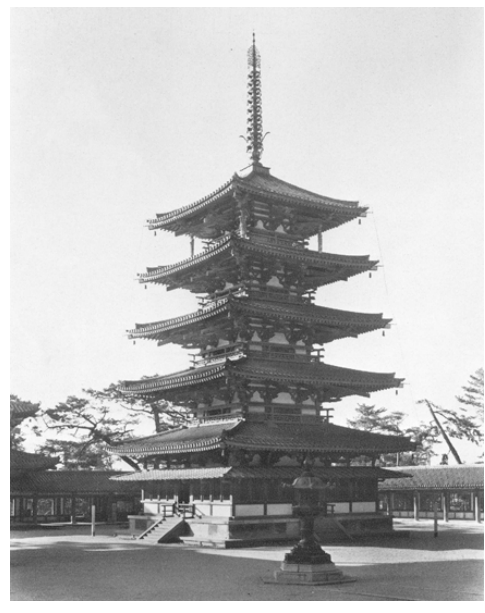

Figure 5: Pagoda in Horyuji Temple.

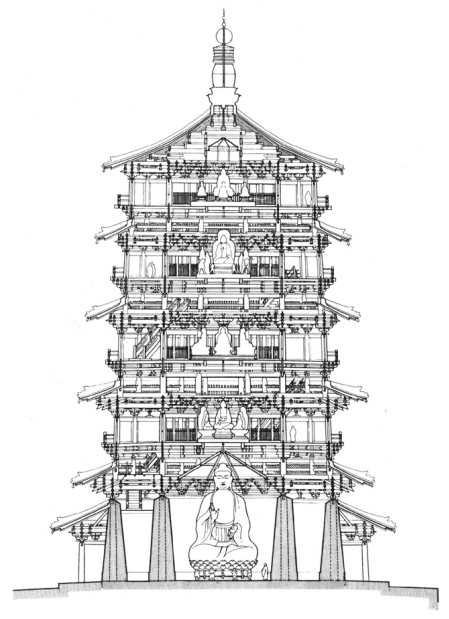

Figure 6: The section of Pagoda at Butsuguji Temple in China.

The plan of the approach from Nandaimon (South Big Gate) to the Saiin (West Compound) has the form of the reverse perspective as this approach becomes wider as much as the observer advances (Fig. 3). Both sides (right and left) of the approach are enclosed with the walls that become higher as the 
observer advances (Fig. 8). Such kind of forms draws the view of the facades (Fig. 4) to the observer. This is another view on this long approach to the Saiin (West Compound).
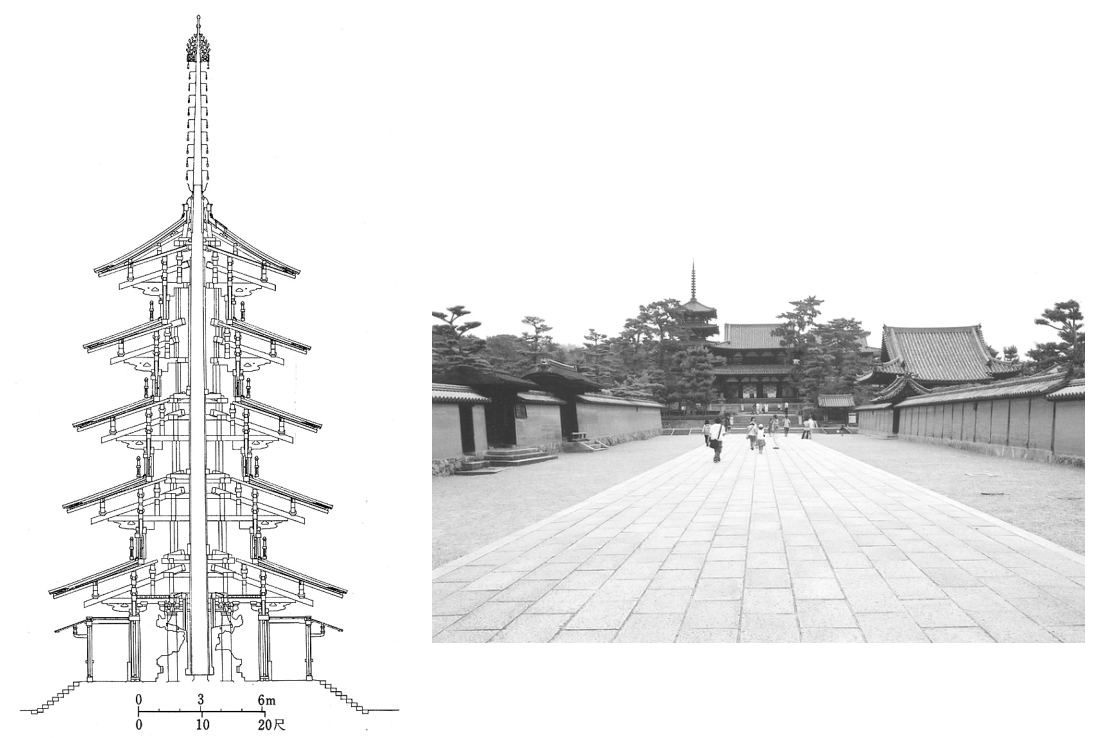

Figure 7: The section of Pagoda Figure 8: The approach from Nandaimon in Horyuji Temple. to the Saiin (West compound).

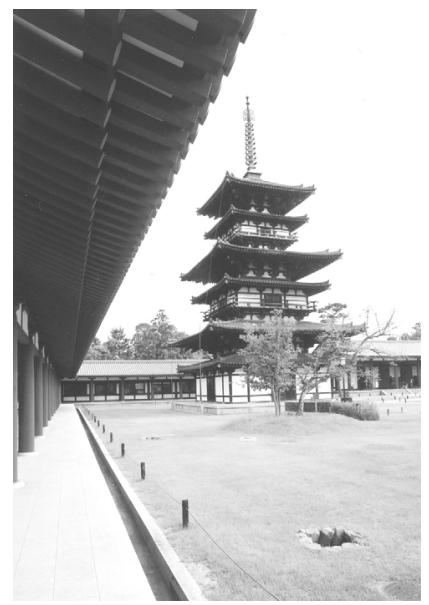

Figure 9: $\quad$ East Pagoda in Yakushiji Temple.

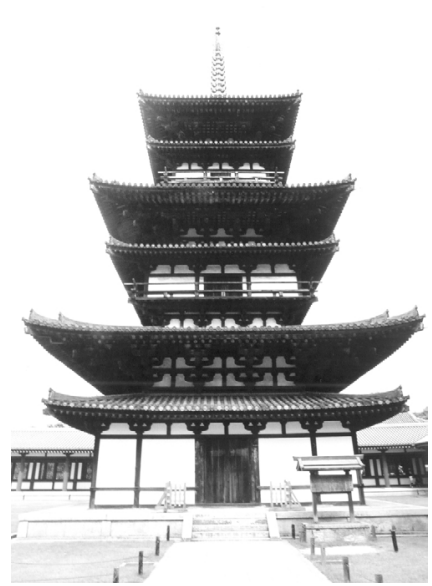

Figure 10: East Pagoda in Yakushiji Temple. 


\section{Concluding remarks}

It is known that Ernest Fenollosa (1853 - 1908, American researcher of Japanese Art) praised East Pagoda (AD 730, Fig. 9) in Yakushiji Temple as "Frozen Music" in the Meiji era. But that comes from the static viewpoint of the observer who stops to watch at that time.

As the observer is approaching to Horyuji Temple, Saiin (West Compound) the spaces are changing according to the influences of "inner domain of eaves" ("inner space of eaves"). Continuously roofs, fascias and eaves appear before the observer's eyes and disappear from his sight. As for the observer it looks like reading and listening the music score like canon and polyphony. The first author of this paper would like to name the changing view, for which beautiful one is suitable, as "Visible Music" from the observer's viewpoint, which the spaces appear with changing. The whole process of the approach felt by the observer's perception is "Visible Music".

Through almost all the ancient Japanese architectures, we can see these characteristics around Japanese traditional buildings because of having roofs and eaves. Though East Pagoda (Fig. 9) in Yakushiji Temple was named as "Frozen Music" it also has the radiation of "the eave's line" and "the roof"s line" on the approach (Fig. 10).

The best one is the case of Horyuji Temple, Saiin (West Compound) because of having the layout of buildings and also having the different shape and heights about every building. Furthermore, that has the approach with reverse perspective and walls. All of these layout, shapes and heights harmonize with each other. "Visible Music" is piped as one approaches Horyuji Temple, Saiin (West Compound).

\section{References}

[1] Yasuhara, M., Research Reports of the Architectural Institute of Japan, Tohoku Branch, No58, pp.51-58, 1995 (in Japanese).

[2] Yasuhara, M., Japanese Space in Architecture, Shinpu-syobou Publishing Co., Ltd.: Osaka, 1996 (in Japanese).

[3] Yasuhara, M., Characterization of Space around Japanese Traditional Buildings. Part 1. The Case of Horyuji Temple. FORMA, Vol.12 No.1, pp. 65-70, The Society for Science on Form, Japan, 1997.

[4] Yasuhara, M., Characterization of Space around Japanese Traditional Buildings. Part 2. The Physical and Psychological Effects of View of Eaves. FORMA, Vol.12 No.1, pp.71-74, The Society for Science on Form, Japan, 1997.

[5] Yasuhara, M., Space of Modern Architecture in Japan, Riko-tosyo Publishing Co., Ltd.: Tokyo, 1998 (in Japanese).

[6] Yasuhara, M., Reading the Space from The Tale of Genji, Kajima Institute Publishing Co., Ltd.: Tokyo, 2000 (in Japanese).

[7] Yasuhara, M., Doctoral Dissertation, Researches Concerning the Characteristics of Space in the Shinden Residence, 2001 (in Japanese). 
[8] Yasuhara, M., Space of Shinden Residential Complex (Shinden-Zukuri). Part 1. Lighting from the side. FORMA, Vol.16 No.4, pp. 367-374, The Society for Science on Form, Japan, 2002.

[9] Yasuhara, M., Introduction to Architecture (Chapter 3 "History of Architectural Space in Japan"), Gakugei Publishing Co., Ltd.: Kyoto, 2003 (in Japanese).

[10] Yasuhara, M., Reading the Space from Seiichi Shirai's Architecture, Gakugei Publishing Co., Ltd.: Kyoto, 2005 (in Japanese). (Seiichi Shirai is a Japanese Architect)

[11] Yasuhara, M., Reading haiku poet Basho from Narrow Roads to Oku, Kajima Institute Publishing Co., Ltd.: Tokyo, 2006 (in Japanese). 